Journal of Advanced Research in Fluid Mechanics and Thermal Sciences

Journal homepage: www.akademiabaru.com/arfmts.html ISSN: $2289-7879$

\title{
Evaluation of Wind Energy Potential in Rayong Province, Thailand by WAsP Program
}

\author{
Watchara Saeheng ${ }^{1}$, Piyanut Saengsikhiao ${ }^{1}$, Juntakan Taweekun ${ }^{2, *}$ \\ Energy Technology Program, Faculty of Engineering, Prince of Songkla University, Hat Yai, Songkhla 90112, Thailand \\ 2 Department of Mechanical and Mechatronics Engineering, Faculty of Engineering, Prince of Songkla University, Hat Yai, Songkhla 90112, \\ Thailand
}

\section{ARTICLE INFO ABSTRACT}

\section{Article history:}

Received 28 January 2021

Received in revised form 23 April 2021

Accepted 26 April 2021

Available online 1 June 2021

Keywords:

Wind power; wind speed; Rayong; wind direction

\begin{abstract}
Over the past decades, wind energy is one of the alternative energy or renewable sources, which has been harvested to produce electricity. Our research aims to study the wind potential of the areas in the Rayong provinces of Thailand. Data from meteorological stations were collected every 10 minutes for of 3 years (2017-2019), with a measuring tower at 10-meter height above ground level (AGL). The annual average wind speeds were investigated in Rayong $(2.02 \mathrm{~m} / \mathrm{s})$ with Weibull Probability Distribution Function (PDF). The annual average power density in Rayong regions was $13 \mathrm{~W} / \mathrm{m}^{2}$. In all locations, wind direction was detected mainly from Southwest (SSW) and the yearly maximum wind power capacity is $94.376 \mathrm{MWh}$. The capacity factor of $21.5 \%$ was noticed. With relatively low wind speed was noticed in Rayong provinces of Thailand, a small wind turbine installed at $\mathbf{3 0}$ meters would be recommended as a cost-effective way to convert wind power to electricity.
\end{abstract}

\section{Introduction}

The exploitation of nonrenewable energy sources, especially coal and natural gas caused the threats to energy security and environmental impacts tremendously over the past decades [1]. The high demand of fossil fuel leads to the uncertainty of energy security which directly affects the global well-being and the economic competitiveness unavoidably [2]. Wind energy is one of the alternative energy or renewable sources, which has been harvested to produce electricity. Several advantages of wind energy have been emphasized including unlimited, clean and environmentally friendly [11].

Global Wind Energy Council reported the growth rate in wind-energy utilization increased dramatically by more than thirty percent (Figure 1) (GWEC, Global Cumulative Installed Capacity 2001-2016) [6]. As the Energy Statistics of Thailand reported that Thailand imported the electricity around $11 \%$ from neighboring countries, Thai government has strategically planned to increase the electricity production from renewable energy by $25 \%$ within the next ten years (2012-2021) according to the alternative energy development plan [7]. The organizations of both government and

\footnotetext{
* Corresponding author.

E-mail address: juntakan.t@psu.ac.th

https://doi.org/10.37934/arfmts.83.2.113
} 
private sector showed interest toward wind electricity generation; moreover, those organizations support the establishment of sustainable ways to generate electricity production from wind power. With the clean and renewable wind energy, we would increase the energy security and attempt to comply with Thailand Twenty-year Efficiency Development Plan or EEDP (2011-2030).

Following the World Bank's reports of wind power potential in South East Asia including Cambodia, Laos, Thailand and Vietnam, the small wind turbines with a tower at $\mathbf{3 0}$ meters are more suitable for Thailand because the low wind speed $(2-5 \mathrm{~m} / \mathrm{s})$ was detected in the most areas in Thailand [8]. The Western, Southern and Eastern Thailand have a good wind regime in the mountain areas [9]. To efficiently produce electricity from wind power using wind turbine generators, we need to scrutinize and select the location with the highest wind power potential for the long-term energy production. To achieve the most efficient electricity production, wind turbine micro-siting including wind speed, wind direction, wind rose, power density, roughness, elevation and environmental factors in each specific site were systematically evaluated [10]. The small wind power installation with a tower of less than 30 meters in Thailand shows the advantages of lowering the costs of installation and maintenance compared to the large wind turbines [12].

In this study, we aim to evaluate the wind energy potential quantitatively at Rayong, Thailand by using collected meteorological data over three year (2017-2019) at the height of $10 \mathrm{~m}$. The simulation data from WAsP was mainly employed to locate the optimal location for the study sites of wind turbine installation.

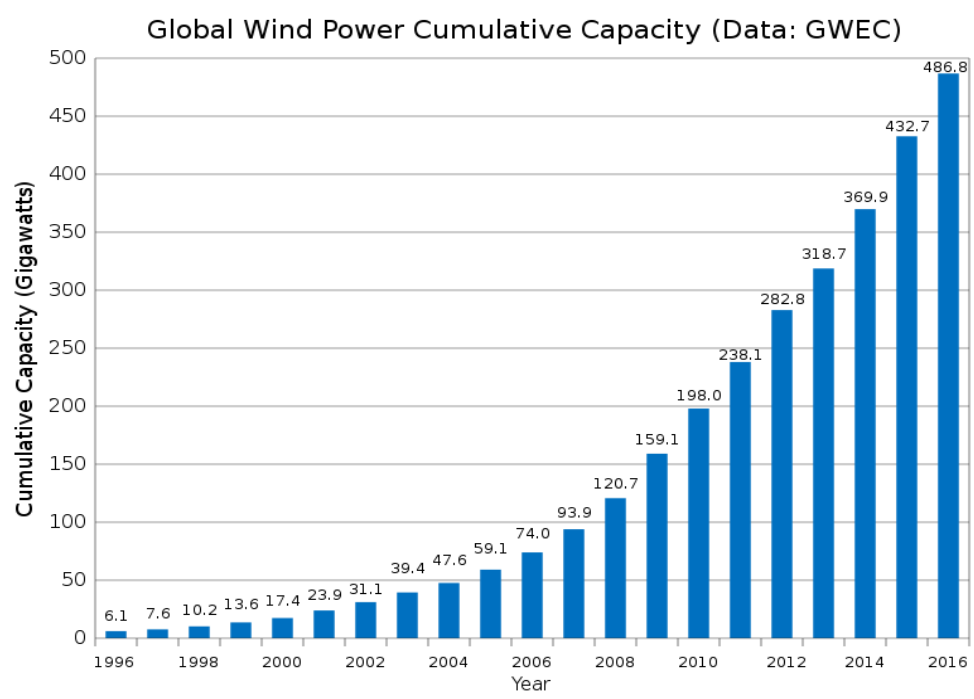

Fig. 1. The growth rate of global installed wind power capacity for electricity production [6]

\section{Methodology}

\subsection{Meteorological Data Collection and Study Sites}

All the meteorological data were obtained from the meteorological stations within the Rayong province and TMD Website. Rayong province is located on the Eastern Thailand and the administrative area in Rayong covers an area of 3,671.489 $\mathrm{km}^{2}$ which was estimated by Geographic Information System (GIS). The geological features of Rayong (Figure 2) consisted of (i) a plain in the North and South of Rayong (ii) a coastal plain with small hills in the Southeast toward Southwest. (iii) The mountain region in the center of Rayong. The geographic location of the meteorological stations was located at $12^{\circ} 38^{\prime} 31.10^{\prime \prime} \mathrm{N}$ and $101^{\circ} 20^{\prime} 37.0^{\prime \prime} \mathrm{E}$. Anemometers which monitored the wind speeds and wind direction were installed on the 10-meter towers above ground level (Figure 3 ). The wind 
towers with mounted anemometers were used to collect all the meteorological measurements which are locates at Rayong meteorological measurements $\left(12^{\circ} 38^{\prime} 01.7^{\prime \prime} \mathrm{N} 101^{\circ} 18^{\prime} 19.3^{\prime \prime} \mathrm{E}\right)$ (Figure 4). In this study, wind data from the agrometeorological station which were collected every ten minutes over a three-year period (January 2017-December 2019) were employed as an input data for (i) calculating the wind speed and wind direction, (ii) generating the wind resource map and (iii) identifying the potential areas for wind energy generation.

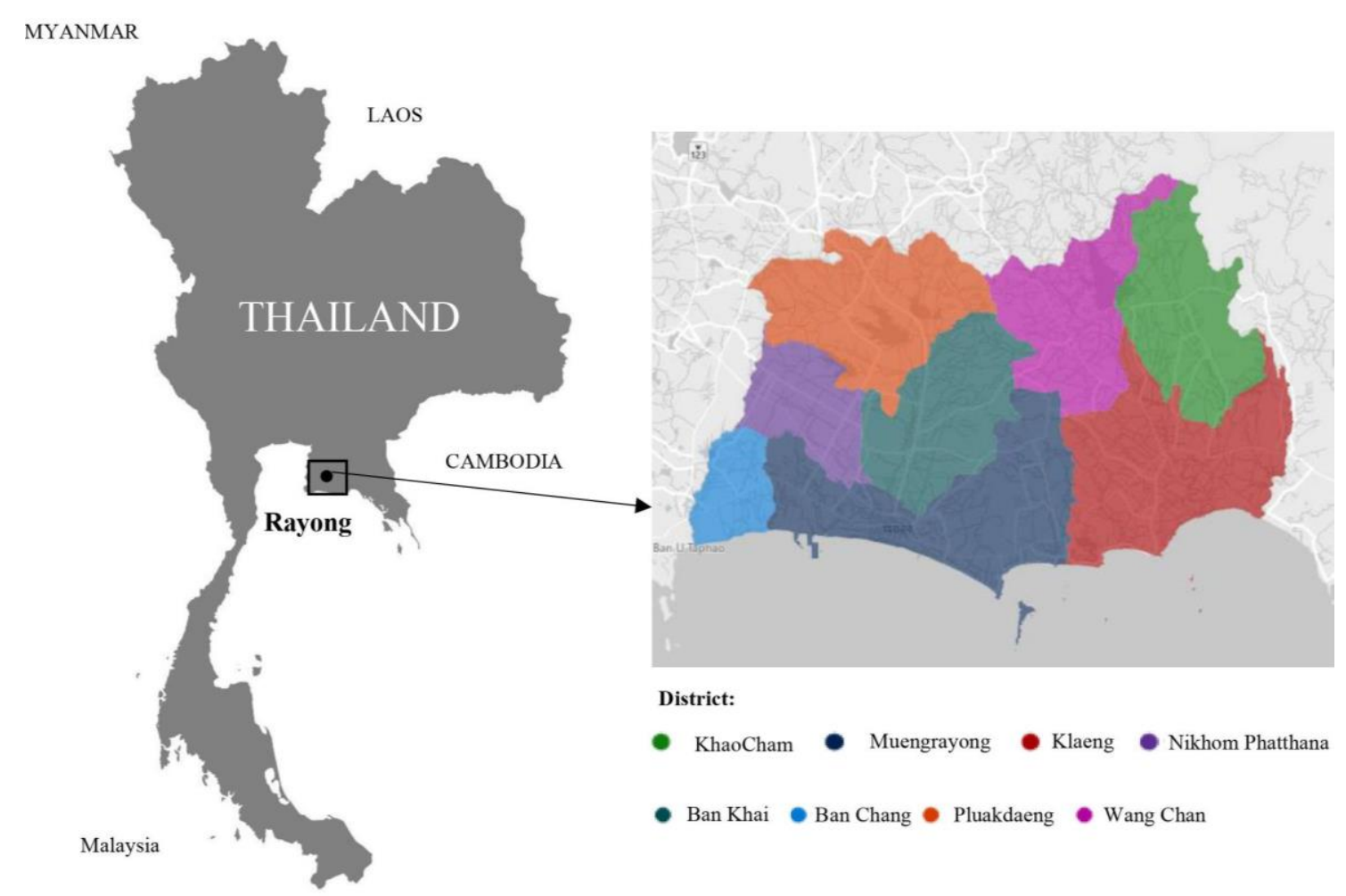

Fig. 2. A map of the geological features of Rayong province [3]

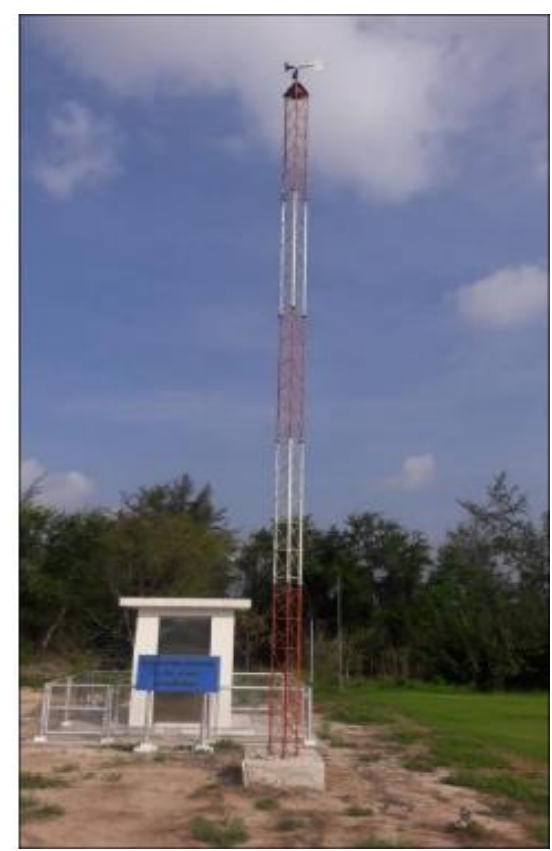

Fig. 3. The wind measuring device at the agrometeorological station [4] 


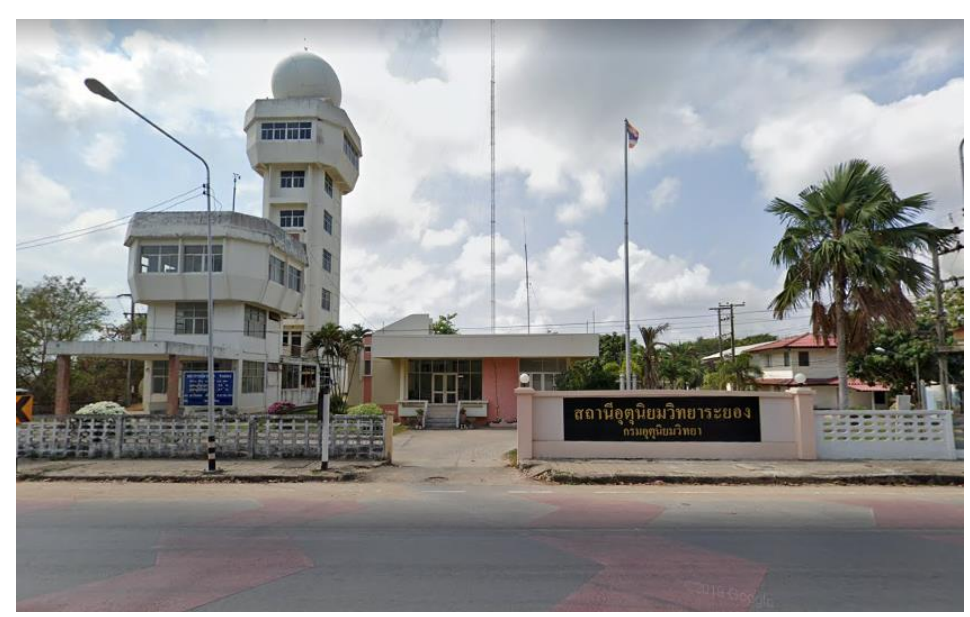

Fig. 4. Rayong meteorological station [4]

\subsection{Potential of Wind Energy and Wind Direction}

By applying the wind data as the input into WAsP program, we were able to generate the average wind velocity, Weibull distribution and wind rose. These parameters were derived from the equation of Weibull distribution. Weibull distribution is one of the most common method that has been used to calculate the wind speed. The Weibull distribution is not required the large size of samples, and it is very flexible. Only two parameters; shape $(k)$ and scale (c) are required for processing the data [14]. We employed the WAsP software which has a package of Weibull distribution. shown as in Eq. (1) which shows continuous probability distribution of any parameters.

$f(V)=\frac{k}{c}\left(\frac{V}{c}\right)^{k-1} \exp \left[-\left(\frac{V}{c}\right)^{k}\right]$

where

$f(V)$ : frequency of incidence of wind speed

$\mathrm{k}$ : shape parameter

c: scale parameter

$\mathrm{v}$ : wind $\operatorname{speed}(\mathrm{m} / \mathrm{s})$

\subsection{Roughness and Elevation Maps}

The roughness and elevation maps were generated by using the WAsP Map Editor tool in WasP program. The geographic location of Rayong meteorological station $\left(12^{\circ} 38^{\prime} 31.10^{\prime \prime} \mathrm{N}\right.$ and $101^{\circ} 20^{\prime}$ $37.0^{\prime \prime} \mathrm{E}$ ) with the grid size of $50 \times 50 \mathrm{~km}^{2}$ (Figure 5) were used to establish the roughness and elevation maps in Rayong. 


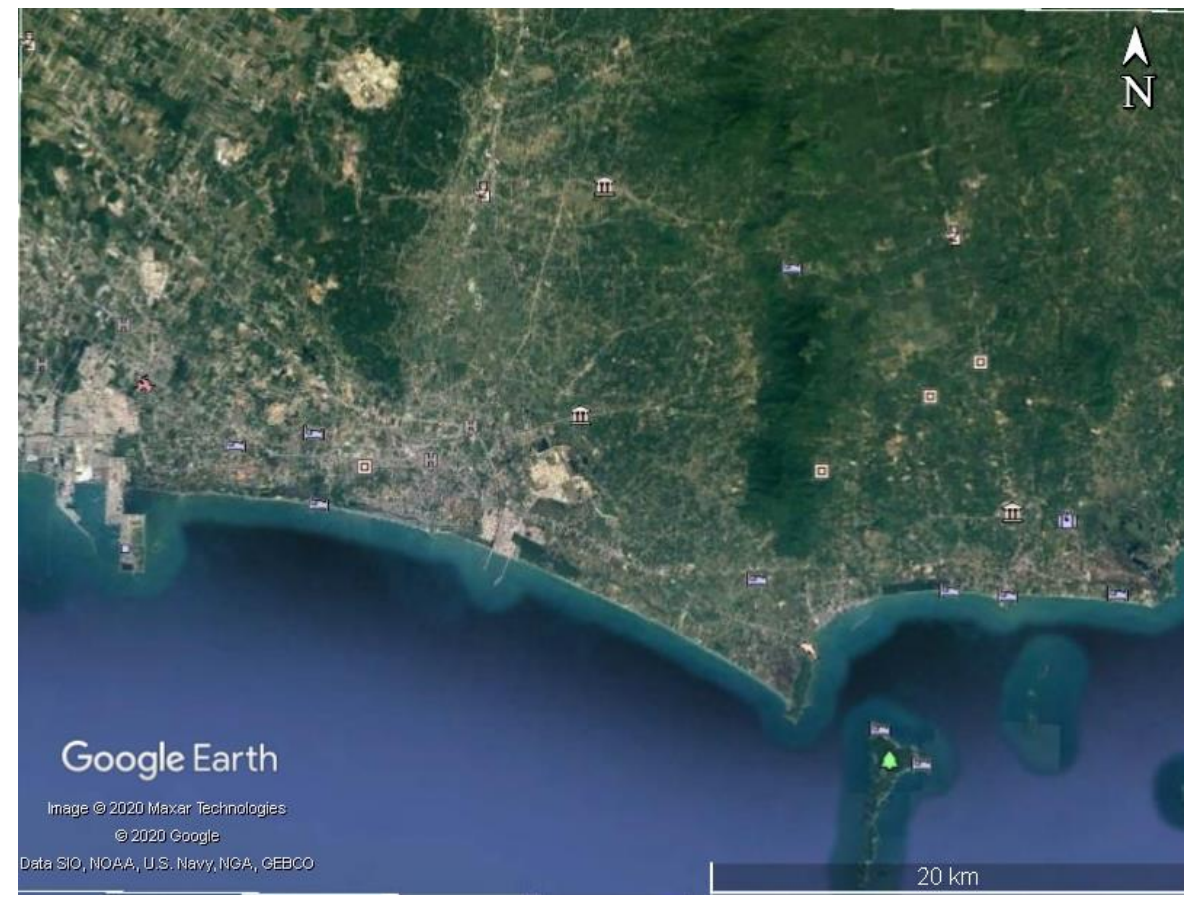

Fig. 5. The satellite image of Rayong Province [5]

\subsection{Annual Average Wind Speed and Annual Average Wind Power Density}

The input data were created from shape file by deriving the data from NASA's Shuttle Radar Topography Mission (SRTM) and the input data were analyzed for (1) the annual average wind speed and (2) the annual average wind power density with WasP program [15].

\subsection{Wind Turbine Power Performance}

The specifications of Hummer 50kW H 17.0 wind turbine (Table 1) and power curve is shown in Figure 6 which is classified as a small-sized turbine was installed at 30 meter above the ground to determine the potential for wind energy application [13]. This type of wind turbine (Hummer 50kW $H$ 17.0) was selected because it can perform at relatively low wind speed around $2.5 \mathrm{~m} / \mathrm{s}$ and it will be stopped when the wind speed exceeds $20 \mathrm{~m} / \mathrm{s}$ as shown in Table 1. To achieve the maximum wind energy potential, the wind turbine installation instruction has been followed to avoid the imbalance of wind turbine blades and inconsistency of capacity factor [16].

Table 1

Hummer H17.0 wind turbine specifications

\begin{tabular}{llllllll}
\hline $\begin{array}{l}\text { Rotor } \\
\text { diameter }\end{array}$ & $\begin{array}{l}\text { Hub } \\
\text { height }\end{array}$ & $\begin{array}{l}\text { Cut-in } \\
\text { speed }\end{array}$ & $\begin{array}{l}\text { Cut-out } \\
\text { speed }\end{array}$ & $\begin{array}{l}\text { Area } \\
\text { Swept }\end{array}$ & $\begin{array}{l}\text { Number of } \\
\text { blades }\end{array}$ & $\begin{array}{l}\text { Rated } \\
\text { power }\end{array}$ & Rated wind speed \\
\hline $17 \mathrm{~m}$ & $30 \mathrm{~m}$ & $2.5 \mathrm{~m} / \mathrm{s}$ & $20 \mathrm{~m} / \mathrm{s}$ & $227 \mathrm{~m}^{2}$ & 3 & $50 \mathrm{~kW}$ & $12.0 \mathrm{~m} / \mathrm{s}$ \\
\hline
\end{tabular}




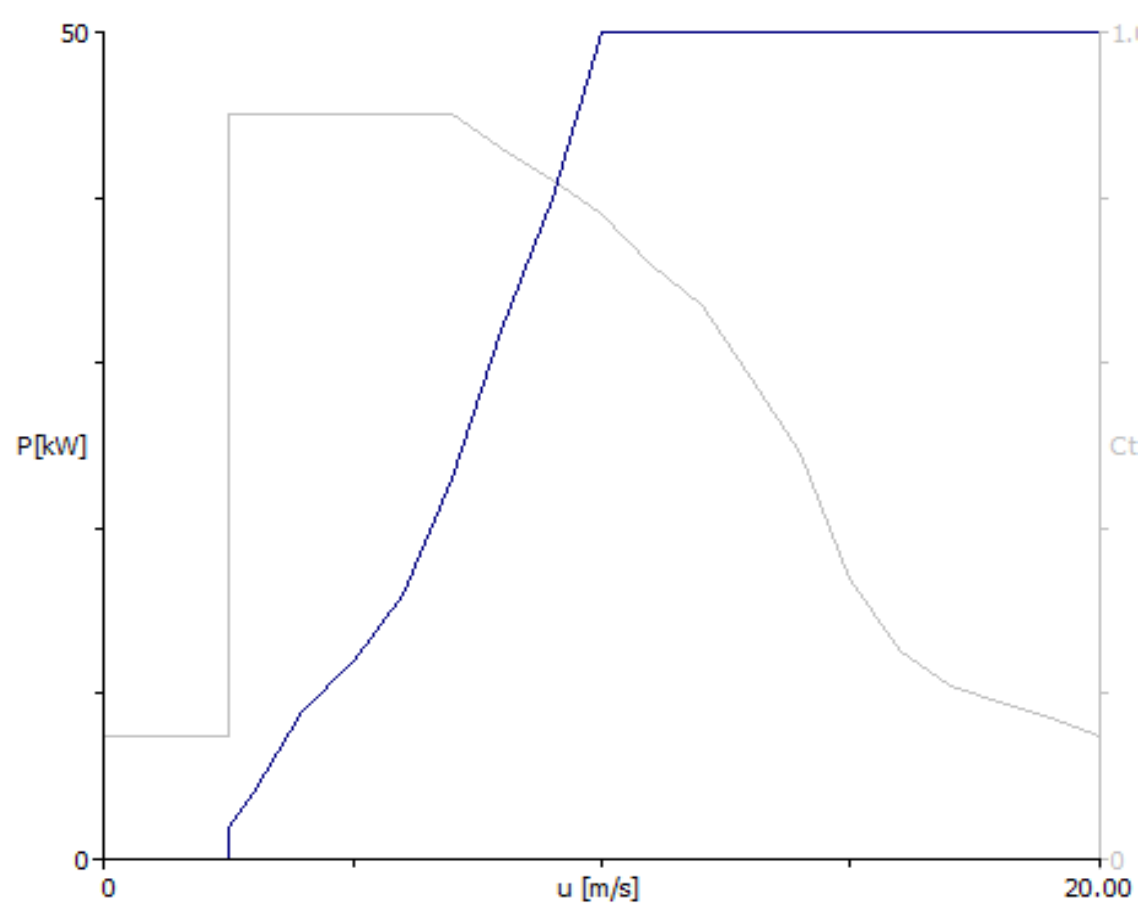

Fig. 6. Power curve of wind turbine generator: Hummer 50kW H 17.0

\section{Results}

\subsection{Meteorological Data Collection and Study Sites}

In this study, the wind speed measurement data from Rayong of Thailand for a period of 3 years (January 2017-December 2019) have been analyzed to generate mean wind speed (U), mean wind direction, mean power density (P), frequency of wind direction ( $f$ ) and Weibull distribution parameters in terms of parameters of $k$ and $A$. The main results obtained from the present study can be summarized as follows.

\subsection{Potential of Wind Energy and Wind Direction}

The wind data were obtained from Rayong meteorological station with Anemometers installed 10-meter above ground level from January 2017 to December 2019. Weibull distribution, which showed the cumulative frequency distribution of wind speed, was used as statistical models of wind data analysis. Together, the Weibull distribution and wind rose provided the annual maximum wind speed wind speed of $3.5 \mathrm{~m} / \mathrm{s}$ and annual wind speed of $2.02 \mathrm{~m} / \mathrm{s}$ in the South-southwest (SSW, 240 degree) (Figure 7). As shown in Table 2, the wind speed that is suitable for wind turbine installation should be greater than $2.5 \mathrm{~m} / \mathrm{s}$ and geographical information of the study site needs to be considered. We were well-aware of the fact that the wind turbine have been installed at 30-meter height above ground level so that we are supposed to measure the wind characteristics at the same height according to the report from the World Bank Group; however, only wind data at 10-meter height above ground level are available from the local Rayong meteorological station. 
Table 2

Sectors-wise wind statistics of the processed data

\begin{tabular}{|c|c|c|c|c|c|c|c|c|c|c|c|c|}
\hline & $0^{\circ}$ & $30^{\circ}$ & $60^{\circ}$ & $90^{\circ}$ & $120^{\circ}$ & $150^{\circ}$ & $180^{\circ}$ & $210^{\circ}$ & $240^{\circ}$ & $270^{\circ}$ & $300^{\circ}$ & $330^{\circ}$ \\
\hline$A[\mathrm{~m} / \mathrm{s}]$ & 1.4 & 1.4 & 1.6 & 1.5 & 1.5 & 1.6 & 1.9 & 2.4 & 3.5 & 3.2 & 1.8 & 1.3 \\
\hline k & 1.95 & 1.81 & 1.55 & 1.58 & 1.69 & 1.75 & 1.79 & 2.12 & 2.55 & 2.46 & 1.57 & 1.84 \\
\hline $\mathrm{U}[\mathrm{m} / \mathrm{s}]$ & 1.22 & 1.29 & 1.45 & 1.37 & 1.33 & 1.45 & 1.65 & 2.13 & 3.06 & 2.85 & 1.66 & 1.19 \\
\hline $\mathrm{P}\left[\mathrm{W} / \mathrm{m}^{2}\right]$ & 2 & 3 & 5 & 4 & 3 & 4 & 6 & 11 & 27 & 23 & 7 & 2 \\
\hline $\mathrm{f}[\%]$ & 4.6 & 8.9 & 6.0 & 4.3 & 5.0 & 6.0 & 9.3 & 14.9 & 21.6 & 13.1 & 3.8 & 2.5 \\
\hline
\end{tabular}
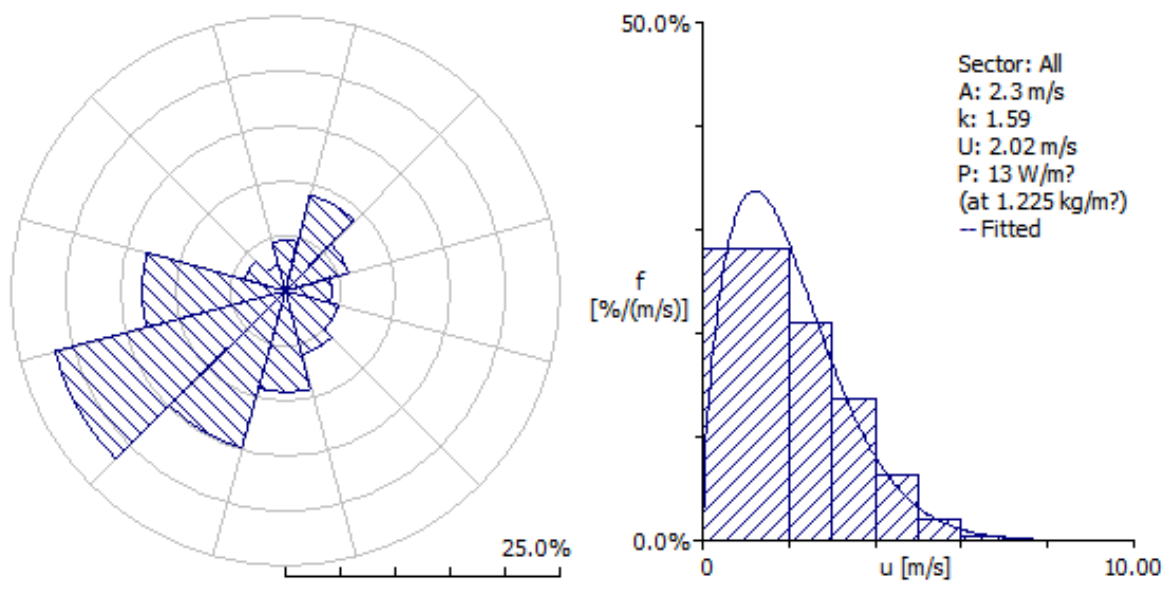

Fig. 7. The wind rose(left) and histogram of wind speed(right)

\subsection{Elevation Map and Roughness Map}

The roughness map and elevation map were created using the WAsP MAP Editor tool from the WAsP program with the grid size of $50 \times 50 \mathrm{~km}^{2}$ to cover the entire area of Rayong province. The analysis indicated that the geological areas of Rayong consisted of both hills and mountains. The maximum height of a mountain was 700 meter above sea level as shown in Figure 8 . The roughness length is $Z_{0}=0.3 \mathrm{~m}$. The terrain showed the roughness class 7 (croplands and forests).

Global Wind Atlas (GWA) warehouse map server and Google Earth maps were used for different land cover categories to classify the roughness lengths. The study area is classified into 7 different roughness lengths Show in the Table 3 corresponding to the actual topographical area of Rayong that has two mountain ranges (Figure 9 ). 


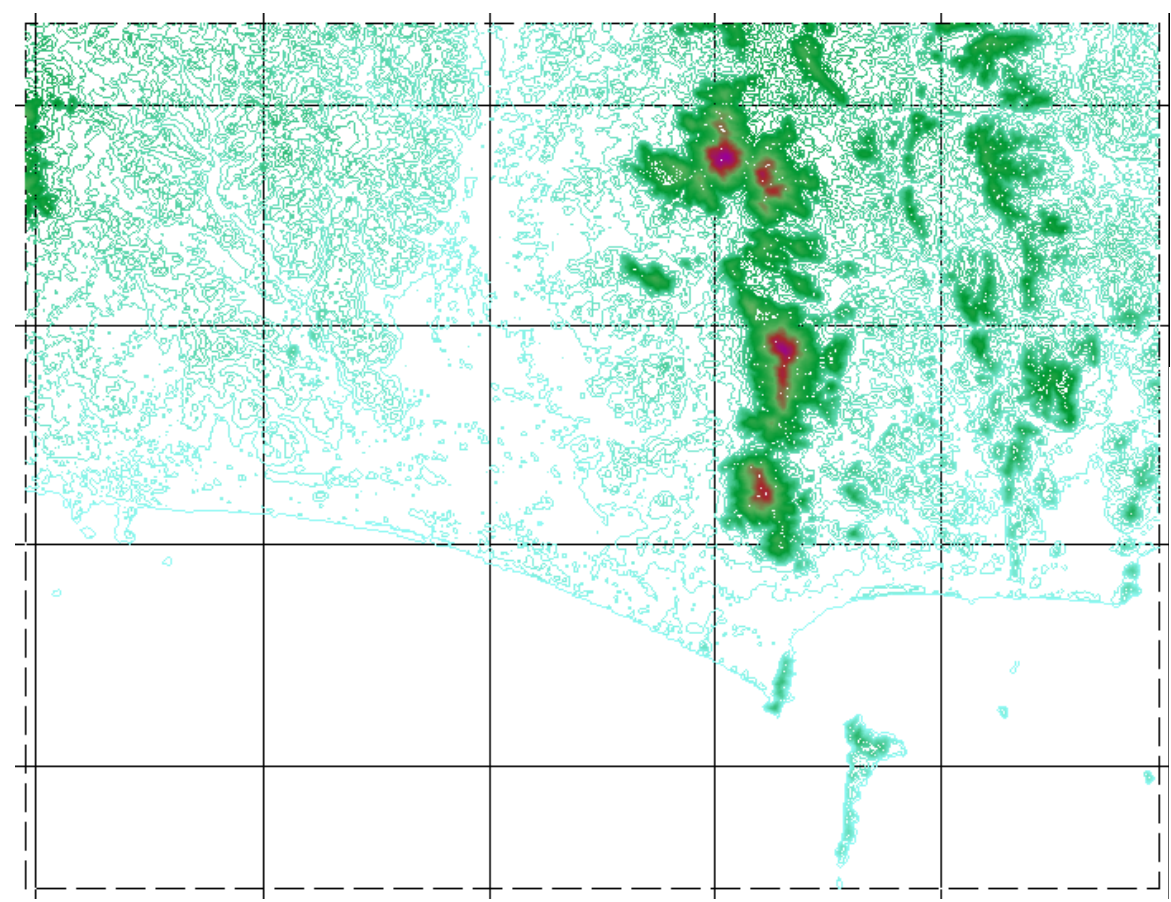

Elevation (m)

$-10$

$-10.00-78.80$

$78.80-167.50$

$167.50-345.00$

$345.00-433.80$

$433.80-522.50$

$522.50-700.00$

Fig. 8. Elevation around the metrological tower

\section{Table 3}

Values of surface roughness for different landcover

\begin{tabular}{lll}
\hline No. & Land Cover Class Name & Roughness Length $Z_{0}(\mathrm{~m})$ \\
\hline 1 & Water surface & 0.0 \\
2 & Bare areas & 0.005 \\
3 & Grassland, savannas or lichens/mosses & 0.03 \\
4 & Croplands & 0.1 \\
5 & Mosaic natural vegetation / cropland & 0.3 \\
6 & Flooded forest or shrubland & 0.6 \\
7 & Forests & 1.5 \\
\hline
\end{tabular}

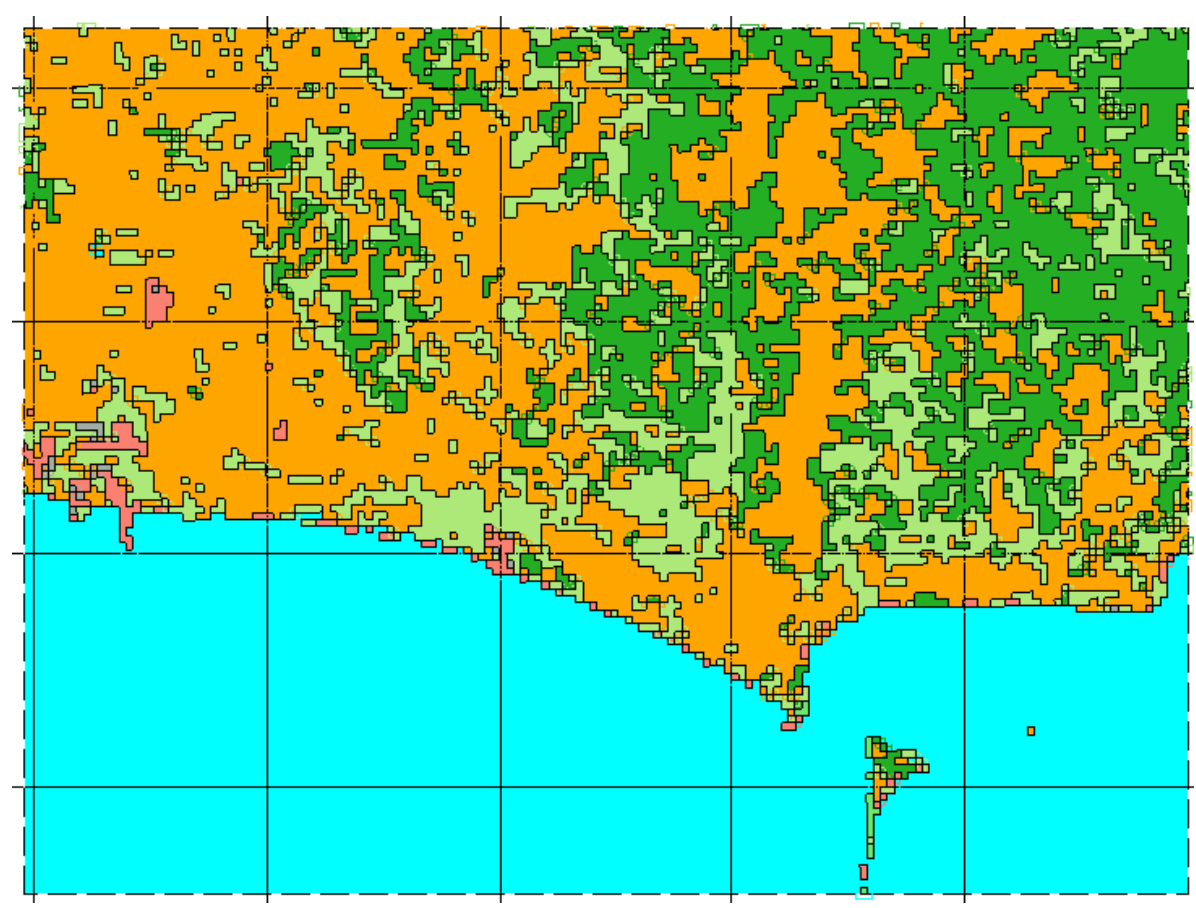

Roughness height $(\mathrm{m})$

$\square 0.000$

0.000-0.005

$0.005-0.030$

$0.030-0.100$

$0.100-0.300$

$0.300-0.600$

$0.600-1.500$

Fig. 9. Roughness height around the metrological tower 


\subsection{Wind Speed Mapping and Wind Power Density}

We used WAsP Map Editor and Shuttle Radar Topography Mission with the grid size of $50 \times 50 \mathrm{~km}^{2}$ and the resolution of $300 \mathrm{~m}$ to analyze the wind map and power density. The geographical distribution of mean yearly wind speed at the height of $10 \mathrm{~m}$ was detected in the range of 0.89-4.56 $\mathrm{m} / \mathrm{s}$. The wind direction was found mainly in the south-southwest direction with the average wind speed greater than $2.5 \mathrm{~m} / \mathrm{s}$. We showed that the wind turbine worked properly at the average wind speed of $2.5 \mathrm{~m} / \mathrm{s}$ as displayed in Figure 10. The wind power density maps illustrated the mean yearly wind speed of $1-120 \mathrm{w} / \mathrm{m}^{2}$ at the height of $10 \mathrm{~m}$ (Figure 11). Based on the evaluation from roughness, elevation maps, wind mapping and power density, the results showed that this area is qualified to install the wind turbine. The wind turbines were installed at six study sites which showed the high potential for wind energy generation.

Both annual average wind speed map and annual average wind power density showed the similar trend as the wind speed gets higher the wind power density is greater as well, or we can conclude that the wind power density varies directly as wind speed.

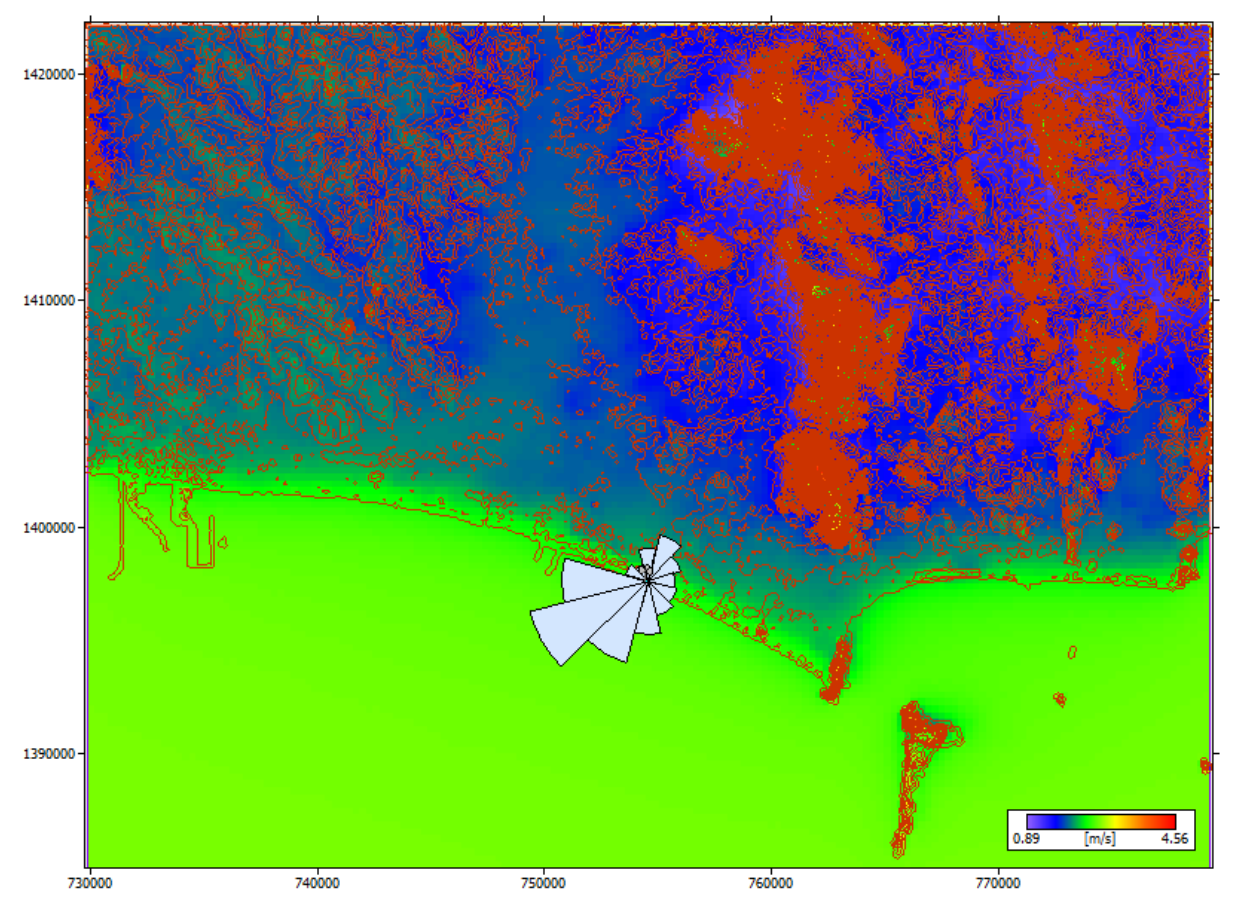

Fig. 10. Estimated Annual Mean Wind Speeds at $10 \mathrm{~m}$ 


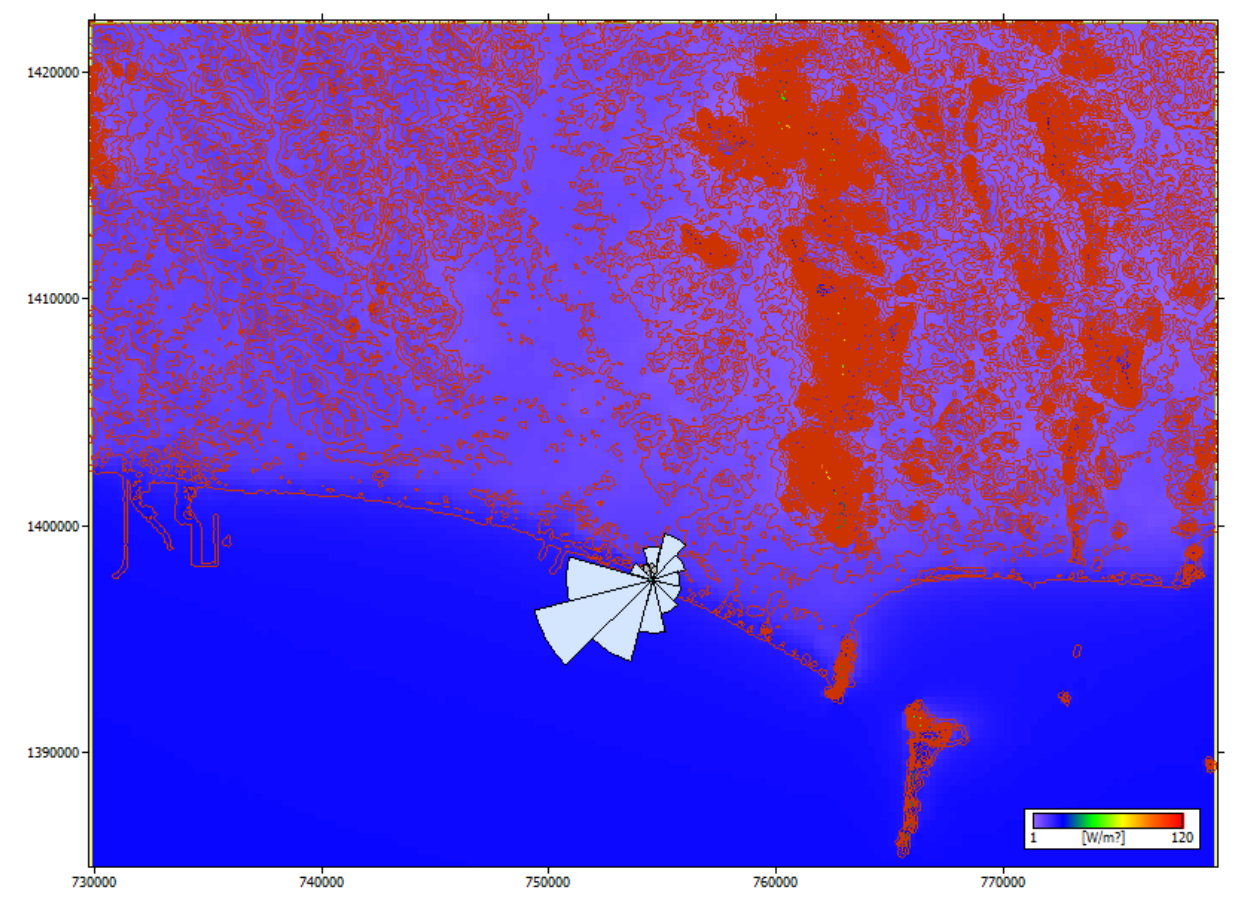

Fig. 11. Estimated Annual Mean Power Density at $10 \mathrm{~m}$

\subsection{Evaluation of Wind Turbine}

As we considered all the key factors including average wind speed map, average wind power density map, the elevation and accessibility of the areas for wind turbine installation, we decided to use the power curve of 50kW Hummer $\mathrm{H} 17.0$ wind turbine at the hub-height of $30 \mathrm{~m}$. We chose this model of wind turbine because the $50 \mathrm{~kW}$ Hummer $\mathrm{H} 17.0$ wind turbine has a cut-in wind velocity of $2.5 \mathrm{~m} / \mathrm{s}$ (Table 1) which was detected in our study sites. We chose the stand-alone wind energy system because it is more convenient for installation, especially at the coastal zone. We installed six wind turbines as shown in Figure 12. Our results of annual energy production (AEP) and the wind power capacity (Table 4) indicated that the third wind turbine showed the best performance of yearly wind power capacity (94.376 MWh) with the capacity factor of $21.5 \%$. The sum of annual energy production in each wind turbine was presented in Figure 13. We optimized some of the parameter including the length between wind turbine, wind speed and wind potential select the best location for turbine wind installation.

\section{Table 4}

Statistical analysis of prospective turbine wind

\begin{tabular}{lllllllll}
\hline $\begin{array}{l}\text { Turbine } \\
\text { Site }\end{array}$ & Location $[\mathrm{m}]$ & $\begin{array}{l}\text { Hub } \\
\text { height } \\
{[\mathrm{m}]}\end{array}$ & $\begin{array}{l}\text { Mean } \\
\text { speed } \\
{[\mathrm{m} / \mathrm{s}]}\end{array}$ & $\begin{array}{l}\text { Power } \\
\text { Density } \\
{\left[\mathrm{w} / \mathrm{m}^{2}\right]}\end{array}$ & $\begin{array}{l}\text { Elevation } \\
{[\mathrm{m}]}\end{array}$ & $\begin{array}{l}\text { Net AEP } \\
{[\mathrm{MWh}]}\end{array}$ & $\begin{array}{l}\text { Wake } \\
\text { loss } \\
{[\%]}\end{array}$ & $\begin{array}{l}\text { Capacity } \\
\text { factor [\%] }\end{array}$ \\
\hline site 1 & $(760564.7,1417562.0)$ & 30.0 & 4.21 & 84 & 678.3 & 87.505 & 0.00 & 20.0 \\
site 2 & $(762087,1416841.0)$ & 30.0 & 4.24 & 95 & 573.8 & 91.499 & 0.00 & 20.9 \\
site 3 & $(762718.9,1409239.0)$ & 30.0 & 4.26 & 104 & 579.2 & 94.376 & 0.00 & 21.5 \\
site 4 & $(762974.4,1407738.0)$ & 30.0 & 4.18 & 106 & 550.7 & 92.404 & 0.00 & 21.1 \\
site 5 & $(761670.0,1403482.0)$ & 30.0 & 4.05 & 89 & 425.5 & 85.812 & 0.00 & 19.6 \\
site 6 & $(762194.8,1402373.0)$ & 30.0 & 4.16 & 91 & 540.0 & 88.574 & 0.00 & 20.2 \\
\hline
\end{tabular}




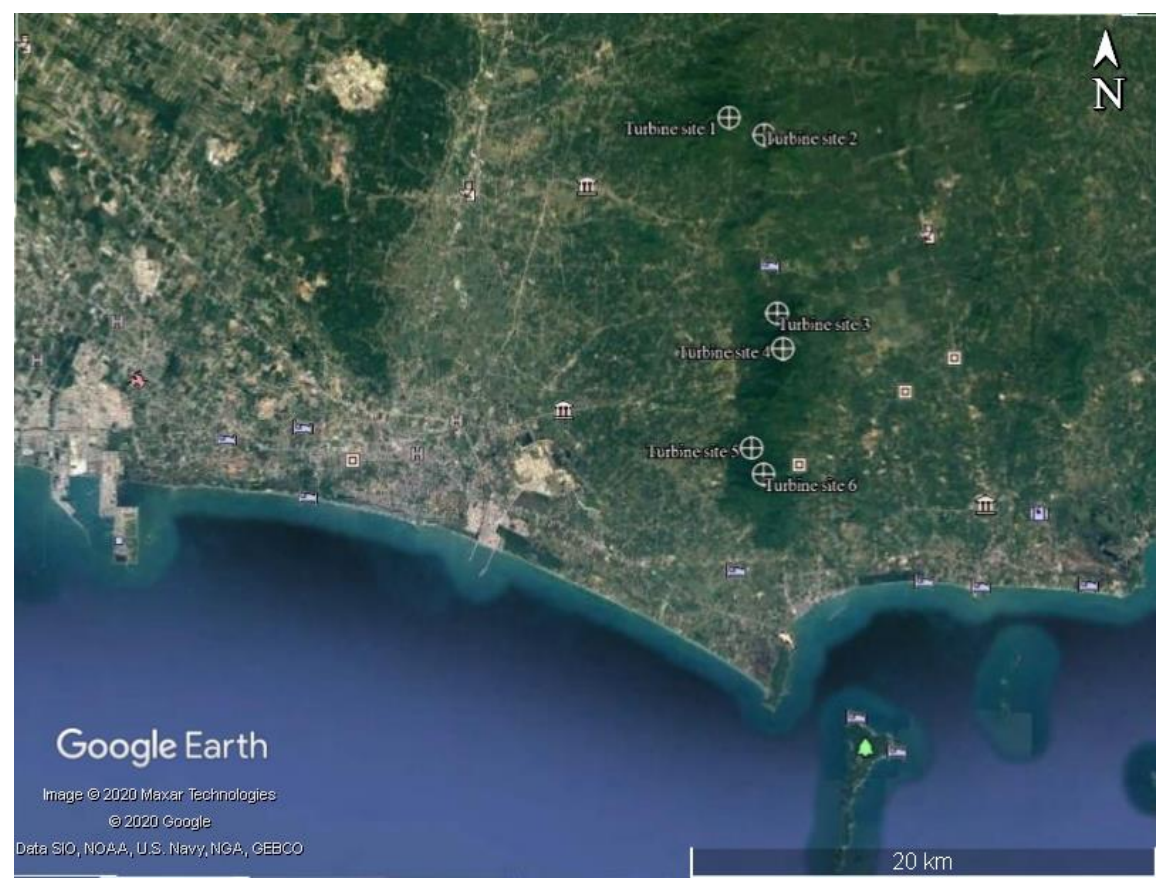

Fig. 12. The study sites with six wind turbines

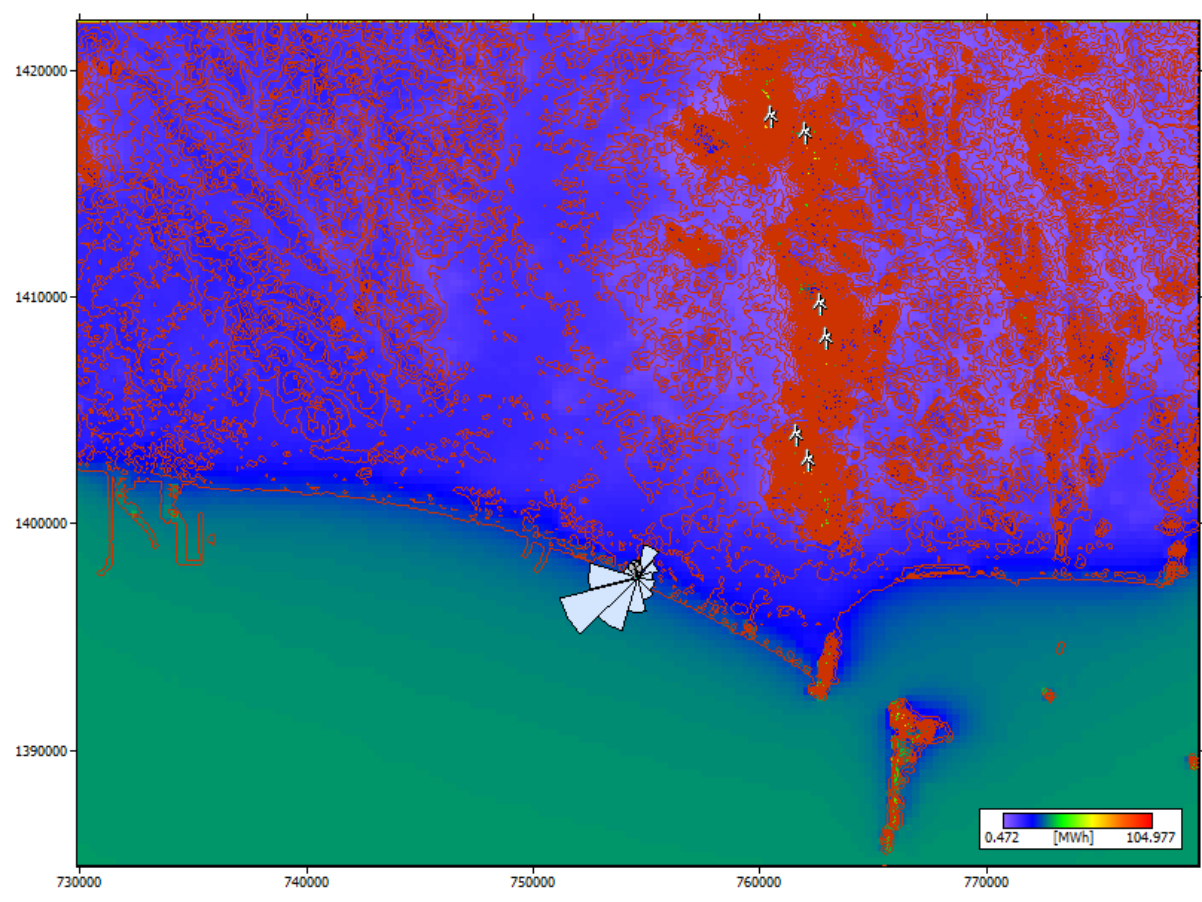

Fig. 13. Estimated Annual Energy Production

\section{Discussion and Conclusions}

In this study, detected the annual maximum wind speed of $3.5 \mathrm{~m} / \mathrm{s}$ and annual wind speed of $2.02 \mathrm{~m} / \mathrm{s}$ in the South-southwest (SSW, 240 degree). Additionally, one previous study in Ubonratchathani Province that measured the wind data at 10-meter height above ground level, which similars to this study, reports the average wind speed of 1.97 to $2.56 \mathrm{~m} / \mathrm{s}$ [18]. Moreover, the researchers from Asian Institute of Technology (AIT) and Thai Meteorological Department investigated the surface wind speed in the Northern Thailand over the decades at the height of $10 \mathrm{~m}$ above ground level. The wind speed was detected from 2-4 m/s [19]. Both previous investigations 
and together with our recent study strongly suggested installing the small wind turbines because the low average wind speed $(2-5 \mathrm{~m} / \mathrm{s})$ was detected.

The wind speed was primarily influenced by the seasonal monsoon. This is likely caused by the southwest monsoon which occurs from May through October [17]. As we used the power curve of the $50 \mathrm{~kW}$ Hummer H 17.0 wind turbine at the hub-height of $30 \mathrm{~m}$, we determined the annual average of wind speed range of $0.89-4.56 \mathrm{~m} / \mathrm{s}$ and annual average of wind power density of $1-120 \mathrm{~W} / \mathrm{m}^{2}$. The wind power capacity indicated that the third wind turbine showed the best performance of yearly maximum wind power capacity ( $94.376 \mathrm{MWh}$ ) with the capacity factor of $21.5 \%$. According to Thakur and Mithulananthan [20], 20-30\% annual capacity factors was quite low but sufficient to produce the electricity in wind farm.

The previous study by Thongyai and Assawamartbunlue [21] illustrated that the greater AEP parameter is obtained with higher wind energy potential. However, some essential parameter might be inadequately optimized such as surface areas, type of the soil and the previous infrastructure of electricity [22-24]. As we previously stated that the wind data at the height of $10 \mathrm{~m}$ is one of our limitations, it is quite challenging to compare our study to others. Still our results of wind turbine evaluation agree with the World Bank's report that detected the low wind speed in Southeast Asia [8].

Our results may be applied as a reference to develop a wind turbine at 30 meters height above ground level in Rayong province of Thailand or the other location with similar wind characteristics in the future. Additionally, a thorough and careful economic analysis would be needed to estimate the specific capital expenditures.

\section{Acknowledgement}

This project would have been impossible without the financial and Facility supported by the Faculty of Engineering at Prince of Songkhla University (PSU). Moreover, we would like to thank Thai Meteorological Department (TMD) for providing information.

\section{References}

[1] Antal, Miklós. "A "parasite market": A competitive market of energy price comparison websites reduces consumer welfare." Energy Policy 138 (2020): 111228. https://doi.org/10.1016/j.enpol.2019.111228

[2] Bianchini, Alessandro. "Trends, Prospects, and R\&D Directions in Wind Turbine Technology." Reference Module in Earth Systems and Environmental Sciences, 2019. https://doi.org/10.1016/B978-0-12-409548-9.11864-0

[3] Ministry of Labor. "Map of Province." Provincial Labour Office Rayong. Accessed January 23, 2021. https://rayong.mol.go.th/en/overall/province-map.

[4] Rayong Government. "Meteorological Station Information, Metadata." Thai Meteorological Department, November 20, 2020. https://pubhtml5.com/azkc/hnif.

[5] Google Earth Maps. "Rayong Province." Google. Accessed January $23,2021$. https://www.google.com/maps/search/rayong.

[6] Chancham, Chana, Jompob Waewsak, Tanate Chaichana, M. Landry, and Y. Gagnon. "Assessment of onshore wind energy potential using regional atmospheric modeling system (RAMS) for Thailand." Energy Procedia 52 (2014): 487-496. https://doi.org/10.1016/i.egypro.2014.07.102

[7] Ciută, Felix. "Conceptual notes on energy security: total or banal security?." Security Dialogue 41, no. 2 (2010): 123144. https://doi.org/10.1177/0967010610361596

[8] Conrad, Olaf, Benjamin Bechtel, Michael Bock, Helge Dietrich, Elke Fischer, Lars Gerlitz, Jan Wehberg, Volker Wichmann, and Jürgen Böhner. "System for automated geoscientific analyses (SAGA) v. 2.1. 4." Geoscientific Model Development 8, no. 7 (2015): 1991-2007. https://doi.org/10.5194/gmd-8-1991-2015

[9] Quan, Pham, and Thananchai Leephakpreeda. "Assessment of wind energy potential for selecting wind turbines: An application to Thailand." Sustainable Energy Technologies and Assessments 11 (2015): 17-26. https://doi.org/10.1016/i.seta.2015.05.002 
[10] Huang, Shuai, Mingming Huang, Yuejun Lyu, and Liwei Xiu. "Effect of sea ice on seismic collapse-resistance performance of wind turbine tower based on a simplified calculation model." Engineering Structures 227 (2021): 111426. https://doi.org/10.1016/j.engstruct.2020.111426

[11] Leung, Dennis Y. C., and Yuan Yang. "Wind energy development and its environmental impact: A review." Renewable and Sustainable Energy Reviews 16, no. 1 (2012): $1031-1039$. https://doi.org/10.1016/i.rser.2011.09.024

[12] Leiserson, Mark, David Lindauer, Oey Astra Meesook, and Parita Suebsaeng. "The World Bank Asia Alternative Energy Program (ASTAE): Status report." The World Bank, Washington D.C. (2004).

[13] de Medeiros, Armando Lúcio Ramos, Alex Maurício Araújo, Oyama Douglas Queiroz de Oliveira Filho, Janardan Rohatgi, and Maurílio José dos Santos. "Analysis of design parameters of large-sized wind turbines by nondimensional model." Energy 93 (2015): 1146-1154. https://doi.org/10.1016/i.energy.2015.09.118

[14] Saberi, Zainab, Ahmad Fudholi, and Kamaruzzaman Sopian. "Fitting of Weibull Distribution Method to Analysis Wind Energy Potential at Kuala Terengganu, Malaysia." Journal of Advanced Research in Fluid Mechanics and Thermal Sciences 66, no. 1 (2020): 1-11. https://doi.org/10.37934/arfmts.69.1.1322

[15] Milligan, Michael R. Measuring wind plant capacity value. No. NREL/TP-441-20493. National Renewable Energy Lab., Golden, CO (United States), 1996.

[16] Mathew, Sathyajith. Wind energy: fundamentals, resource analysis and economics. Springer, 2006.

[17] Sedaghat, Ahmad, Fadi Alkhatib, Armin Eilaghi, Mohamad Sabati, Leila Borvayeh, and Ali Mostafaeipour. "A new strategy for wind turbine selection using optimization based on rated wind speed." Energy Procedia 160 (2019): 582-589. https://doi.org/10.1016/j.egypro.2019.02.209

[18] Sedaghat, Ahmad, Arash Hassanzadeh, Jamaloddin Jamali, Ali Mostafaeipour, and Wei-Hsin Chen. "Determination of rated wind speed for maximum annual energy production of variable speed wind turbines." Applied Energy 205 (2017): 781-789. https://doi.org/10.1016/i.apenergy.2017.08.079

[19] Sun, Haiying, Xiaoxia Gao, and Hongxing Yang. "A review of full-scale wind-field measurements of the wind-turbine wake effect and a measurement of the wake-interaction effect." Renewable and Sustainable Energy Reviews 132 (2020): 110042. https://doi.org/10.1016/i.rser.2020.110042

[20] Thakur, Devbratta, and Nadarajah Mithulananthan. "Wind energy in Thailand to enhance energy security: potential, status and barriers." International Energy Journal 11, no. 4 (2010): 203-212.

[21] Thongyai, Naruwit, and Kriengkrai Assawamartbunlue. "Wind atlas of Chanthaburi and Trat provinces, Thailand." Energy Procedia 141 (2017): 389-393. https://doi.org/10.1016/i.egypro.2017.11.048

[22] Unchai, Thitipong, Adun Janyalertadun, and Arne Erik Holdø. "Wind energy potential assessment as power generation source in Ubonratchathani Province, Thailand." Wind Engineering 36, no. 2 (2012): 131-143. https://doi.org/10.1260/0309-524X.36.2.131

[23] Waewsak, J., T. Chaichana, C. Chancham, M. Landry, and Y. Gagnonc. "Micro-siting wind resource assessment and near Shore wind farm analysis in Pakpanang district, Nakhon Si Thammarat province, Thailand." Energy Procedia 52 (2014): 204-215. https://doi.org/10.1016/j.egypro.2014.07.071

[24] Werapun, Warit, Yutthana Tirawanichakul, and Jompob Waewsak. "Comparative study of five methods to estimate Weibull parameters for wind speed on Phangan Island, Thailand." Energy Procedia 79 (2015): 976-981. https://doi.org/10.1016/j.egypro.2015.11.596 